\title{
Giant bezoar: young Rapunzel
}

\author{
Carlos André Barrso Oliveira, ${ }^{1}$ Teresa Dionisio, ${ }^{2}$ Marlene Silva ${ }^{3}$
}

${ }^{1}$ Radiology, Hospital de Braga, Braga, Braga, Portugal

${ }^{2}$ Radiology, Hospital de Braga, Guimaraes, Portugal

${ }^{3}$ Family Medicine, Centro de Saude de Baião, Fafe, Portugal

\section{Correspondence to}

Dr Carlos André Barrso Oliveira, carlosaboliveira2014@gmail. com

Accepted 14 February 2018

\section{DESCRIPTION}

Surgeons and radiologists encounter a challenge regarding the type of diagnostic imaging techniques to use when faced with a possible small bowel obstruction (SBO). However, with a sensitivity of $82 \%-100 \%$ for high-grade and complete SBOs, multidetector CT is the preferred imaging method. ${ }^{12}$

A high-grade obstruction can be identified by the degree of distal collapse, proximal bowel dilation and small bowel faeces sign. ${ }^{23}$

The transition point is defined by a calibre change between the dilated proximal and collapsed distal small bowel loops. ${ }^{12}$

Bezoars are an unusual cause of acute abdomen due to SBO (1-2), causing a mostly complete mechanical obstruction. Bezoars are commonly located in the jejunum or in the proximal ileum. ${ }^{1-3}$

Our images demonstrate the importance of CT for bezoar identification (figures 1 and 2) and for definition of the transition point (figures 3 and 4). The small bowel faeces sign can be clearly seen in the coronal view (figure 4). In addition, the sagittal view helps the radiologist in the diagnosis.

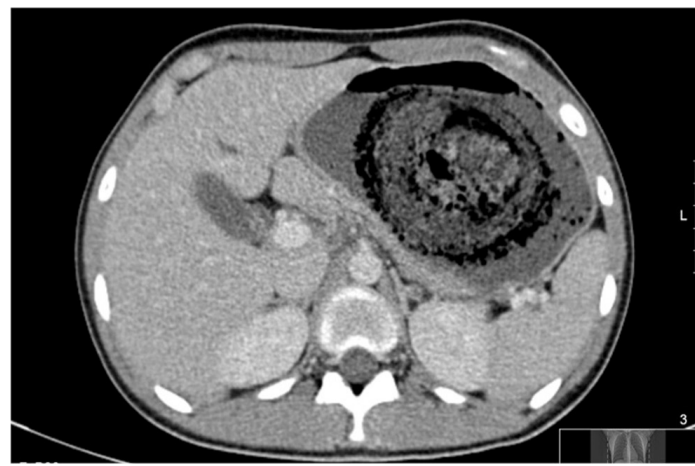

Figure 1 Axial CT-marked gastric distension by hair.

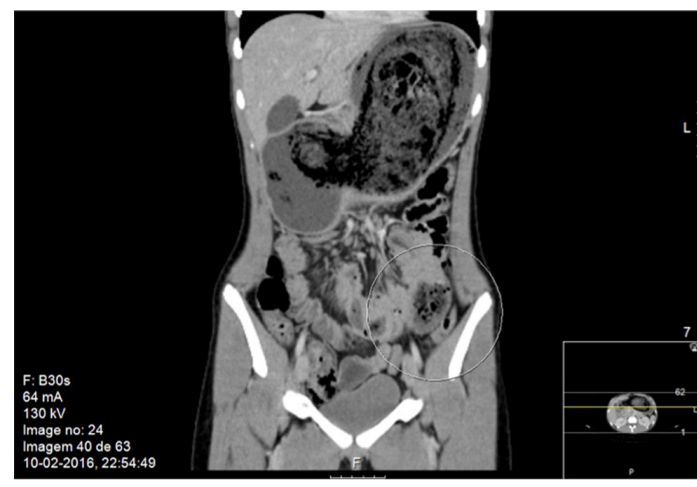

Figure 2 Marked distention of stomach and colon with clearly defined transition point.
The treatment for the present case was based on correcting physiological disturbances, and the patient was put on bowel rest. Open laparotomy was performed for bezoar removal and small bowel resection. The patient remained stable and asymptomatic throughout the follow-up with a periodicity of 6-6 months.

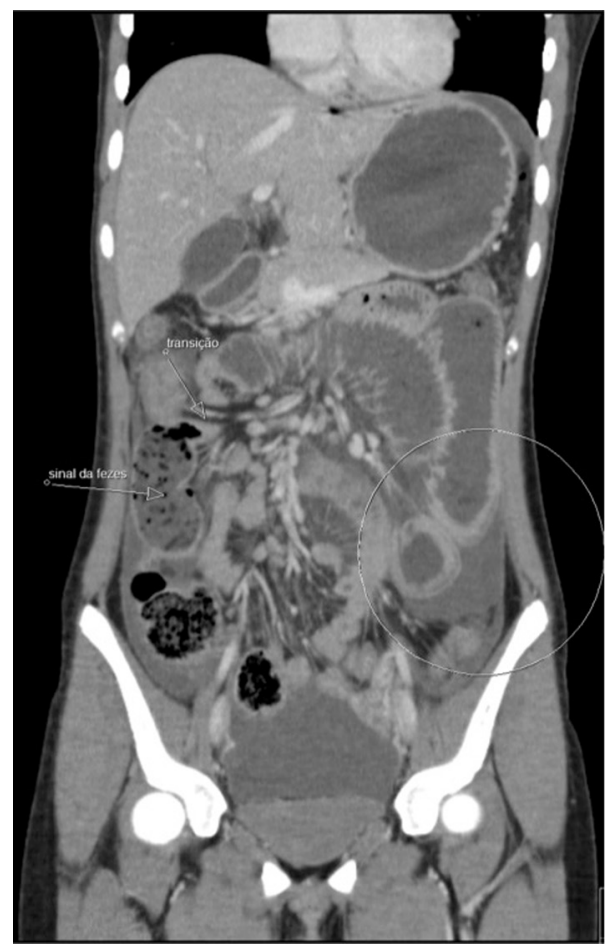

Figure 3 Sagittal view: hair mass distending the stomach.

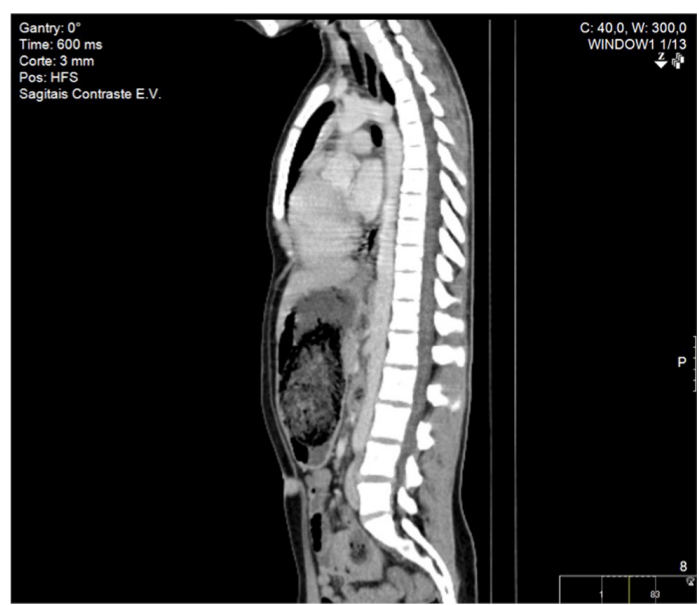

Figure 4 Coronal view: transition point and small bowel faeces sign. 


\section{Learning points}

- Trichophagia is an uncommon psychiatric pathology.

- Remote causes for intestinal obstruction should always be taken into account for the differential diagnosis.

- Ultrasound can help in intestinal obstruction.

Contributors CABO reported the ultrasound and CT with the help of TD. The plan to the case report was all from the CABO. TD and MS helped in image selection. MS reviewed all the work including the English.

Funding This research received no specific grant from any funding agency in the public, commercial or not-for-profit sectors.

Disclaimer There is absolutely no relation between the coauthor and the patient guardian and they just share a common surname in Portugal.
Competing interests None declared.

Patient consent Guardian consent obtained.

Provenance and peer review Not commissioned; externally peer reviewed.

(C) BMJ Publishing Group Ltd (unless otherwise stated in the text of the article) 2018. All rights reserved. No commercial use is permitted unless otherwise expressly granted.

\section{REFERENCES}

1 Singh J, Kumar R, Kalyanpur A. "Small bowel feces sign" - a ct sign in small bowel obstruction. Indian J Radiol Imaging 2006;16:71-4.

2 Canon CL. et alGastrointestinal tract. In: JKT L, Sa- gel SS, Stanley RJ, Heiken JP, . eds. Computed body tomography with MRI correlation. 4th edn. Philadelphia: Pa: Lippincott Williams \& Wilkins, 2006:771-828.

3 Lazarus DE, Slywotsky C, Bennett GL, et al. Frequency and relevance of the "small-bowel feces" sign on CT in patients with small-bowel obstruction. AJR Am J Roentgenol 2004;183:1361-6.

Copyright 2018 BMJ Publishing Group. All rights reserved. For permission to reuse any of this content visit

http://group.bmj.com/group/rights-licensing/permissions.

BMJ Case Report Fellows may re-use this article for personal use and teaching without any further permission.

Become a Fellow of BMJ Case Reports today and you can:

- Submit as many cases as you like

- Enjoy fast sympathetic peer review and rapid publication of accepted articles

- Access all the published articles

- Re-use any of the published material for personal use and teaching without further permission

For information on Institutional Fellowships contact consortiasales@bmjgroup.com

Visit casereports.bmj.com for more articles like this and to become a Fellow 